\title{
Ne pas jeter le bébé avec l'eau de son bain. A propos d'Artemisia afra
}

\section{J-F Pays}

Reçu le 9 août 2019; accepté le 12 août 2019

(C) Société de pathologie exotique et Lavoisier SAS 2019

La publication du dernier rapport OMS sur le paludisme (novembre 2018, concernant l'année 2017) [3] constate que toutes les craintes qui avaient été formulées et reprises dans un ensemble de réflexions publié dans le Bulletin de la Société de pathologie exotique en 2010 [5] sont devenues aujourd'hui des réalités : quasi-stagnation depuis 2015 de la morbidité (219 millions de cas contre 239 millions en 2010) et de la mortalité (435 000 décès annuels, au lieu d'un chiffre proche de zéro promis pour 2015, si on s'en réfère aux objectifs du Programme mondial de lutte contre le paludisme lorsque celui-ci a pris le relai de Roll Back Malaria en 2010), échec de l'universalité de la couverture par les moustiquaires imprégnées d'insecticide à longue durée d'action (MILD ou MILDA) dont ne bénéficie aujourd'hui qu'une petite moitié de la population africaine à risque, associé à une résistance d'importance croissante des anophèles aux pyréthrinoïdes qui en sont le fer de lance, adaptation des vecteurs aux contraintes générées par l'ensemble des moyens de lutte antivectorielle... [3], tout cela dans le contexte d'une résistance de plus en plus préoccupante de $P$. falciparum aux combinaisons thérapeutiques à base d'artémisinine (CTA) et de l'entrée en scène d'un vaccin dont l'efficacité plus que médiocre (40\% dans le meilleur des cas), le condamnerait, en d'autres circonstances, à rester au placard [2].

Comme ces aristocrates de la Restauration dont Talleyrand disait qu'ils n'avaient rien oublié et rien appris, les responsables de la Stratégie technique mondiale de lutte contre le paludisme qui disposent aujourd'hui d'un budget annuel de 3 milliards de dollars, mais qui en réclament plus du double, s'étaient fixés en 2016, comme objectif intermédiaire 2020, une réduction de $40 \%$ de la morbidité et de la mortalité du paludisme par rapport à 2015, et, à plus long terme, de $90 \%$ en 2030. L'OMS a d'ores et déjà entériné le fait que les objectifs de moyen terme seront une fois de plus loin d'être atteints [4). Tout ce qui touche au traitement

J-F Pays $(\bowtie)$

Co-rédacteur du Bulletin de la Société de pathologie exotique,

e-mail : jeanfrancoispays@gmail.com

Hôpital Pitié-Salpêtrière, 47-83 bld de l'Hôpital,

75651 Paris cedex 13, France et à la prévention du paludisme à $P$. falciparum est donc plus que jamais d'actualité.

Ce qu'il fallait dire au sujet de l'incitation à utiliser dans ce cadre, en monothérapie par voie orale et sous forme de tisane, donc à des doses qui ne peuvent être contrôlées, la plante dont est extraite l'artémisinine a été à juste titre dit à plusieurs reprises dans notre Bulletin et ailleurs. Il est un point sur lequel nous voudrions toutefois revenir : les tisanes préparées avec des feuilles séchées d'Artemisia afra feraient jeu égal avec celles d'Artemisia annua dans le traitement des accès de paludisme, alors qu'Artemisia afra ne contient pratiquement pas d'artémisinine $(0,036 \mathrm{mg} / \mathrm{gr}$ de feuilles sèches versus 1,35 à $1,70 \mathrm{mg}$ pour Artemisia annua). C'est du moins ce que prétendent les promoteurs et les défenseurs des tisanes d'Artemisia spp à la suite d'un essai randomisé en double insu [1] portant sur 943 patients et comparant respectivement l'activité de l'ASAQ aux tisanes d'Artemisia annua et d'Artemisia afra dans le traitement des accès simples de paludisme à $P$. falciparum. L'article qui en rend compte est critiquable sur de nombreux points. À moins de postuler d'emblée que les résultats rapportés ne correspondent en rien à la réalité, il n'en reste pas moins que ceux qui concernent Artemisia afra vont à l'encontre de toutes les attentes et de toute logique. Leur confirmation par des équipes travaillant sans a priori et en dehors de tout positionnement idéologique pourrait témoigner de la présence, dans les feuilles séchées de cette espèce d'armoise, soit d'une molécule autre que l'artémisinine, mais qui aurait une activité antipaludique semblable, ce que ne confirme pas les tests in vitro, soit d'une pro-drogue susceptible d'acquérir cette activité après avoir été métabolisée, soit enfin de plusieurs molécules, inactives prises isolément, mais qui tireraient leur activité antipaludique in vivo de leur association, sans que l'on puisse parler véritablement de polychimiothérapie comme certains ne manqueraient probablement pas, dans ce cas, de le faire. Dans l'état actuel de nos connaissances, l'idée même de l'existence d'une propriété antipaludique de certaines armoises en dehors d'Artemisia annua et de son artémisinine est sans nul doute difficile à admettre, mais refuser ne serait-ce que de l'envisager et d'essayer de savoir si cela correspond à un phantasme ou à une réalité serait un peu comme risquer de jeter le bébé avec l'eau de son bain, et 
finalement peu conforme à l'esprit scientifique. Il va sans dire que le fait d'entreprendre une telle démarche ne devrait modifier en rien la stricte interdiction d'utiliser l'artémisi- nine en monothérapie orale, que ce soit pour prévenir et traiter le paludisme et, à plus forte raison, la bilharziose, ou encore améliorer la réponse immunitaire des sidéens.

\section{Don't Throw the Baby out with the Bathwater. About Artemisia afra}

The publication of the latest 2018 WHO malaria report concerning the year 2017 [3] verifies that all the fears that were formulated and included in a series of discussions published in the Bulletin of the Société de pathologie exotique in 2010 [5] have become today realities: quasistagnation since 2015 of morbidity (219 million cases against 239 million in 2010) and mortality (435,000 deaths annually, instead of a number close to 0 promised for 2015 if we refer to the objectives of the Global Malaria Control Program when it took over from Roll Back Malaria in 2010), failure of universality of long-lasting insecticide-treated bednets coverage (LLINs) that barely benefits today to half of the african population at risk, associated with an increasing resistance of Anopheles to the pyrethroids which are the spearhead of it, vector adaptation to constraints generated by all means of vector control... [3], all in the context of a more and more worrying resistance of $P$. falciparum to artemisinin-based combination therapies (ACTs) and arrival of a vaccine whose quite poor effectiveness $(40 \%$ in the best case) would condemn it, in other circumstances, to remain in the closet [2].

As these aristocrats of the French Restoration, whose Talleyrand said they had forgotten nothing and nothing learned, the people in charge of the Global Technical Strategy against Malaria who now have an annual budget of $\$ 3$ billions, but who claim more than twice, had set in early 2016, as an interim target of 2020 , a reduction of $40 \%$ in the morbidity and mortality of malaria compared to 2015 and, in the longer term, $90 \%$ in 2030 . WHO has already endorsed the fact that the medium-term goals will once again be far from being achieved [4]. All that concerns the treatment and prevention of $P$. falciparum malaria is therefore more relevant than ever.

What should be said about the incitement to use in this context, in oral monotherapy and in the form of herbal tea, so at doses that cannot be controlled, the plant from which artemisinin is extracted, has been rightly said many times in our Bulletin and elsewhere. There is one point however we would like to revisit: herbal tea made from dried leaves of Artemisia afra would match those of Artemisia annua in the treatment of malaria, while Artemisia afra contains virtually no artemisinin $(0.036 \mathrm{mg} / \mathrm{gr}$ dry leaves versus $1.35-1.70 \mathrm{mg}$ for Artemisia annua). This is at least what is claimed by the promoters and defenders of Artemisia spp herbal teas following a randomized double-blind trial [1] involving 943 patients and comparing respectively the ASAQ's acti- vity with Artemisia annua and Artemisia afra herbal teas in the treatment of uncomplicated $P$. falciparum malaria episodes. The article that reports this fact is open to criticism on many points. Unless you immediately postulate that the results reported with Artemisia afra do not correspond to reality, the fact remains that these results are against all expectations and logic. If they were confirmed by teams working without a priori and apart from any ideological positioning, these teams could demonstrate the presence, in the dried leaves of this species of sagebrush, either of a molecule other than artemisinin, but which would also have a major antimalarial activity, which is not confirmed by in vitro tests, or of a prodrug likely to acquire it after having been metabolized, or, finally, of several inactive molecules taken in isolation, but which would draw their antimalarial activity in vivo from their association, though it cannot be said that it is a real multidrug therapy as some would probably not, in this case, fail to do. In the present state of our knowledge, the idea of the existence of an antimalarial property of certain sagebrush outside Artemisia annua and its artemisinin is undoubtedly difficult to admit, but refusing to even consider it, and refusing to try to find out if it is fantasy or reality would be a bit like throwing the baby out with the bathwater, and finally not in line with the scientific spirit. It goes without saying that undertaking such an approach should not in any way alter the strict prohibition on the use of artemisinin in oral monotherapy, whether for the prevention and treatment of malaria and, even more so, bilharzia, or to improve the immune response of AIDS patients.

\section{Références}

1. Munyangi J, Cornet-Vernet L, Idumbo M, et al (2019) Artemisia annua and Artemisia afra tea infusions vs. artesunate-amodiaquine (ASAQ) in treating Plasmodium falciparum malaria in a large scale, double blind, randomized clinical trial. Phytomedicine 57:49-56. doi: 10.1016/j.phymed.2018.12.002. Epub 2018 Dec 5.

2. OMS (2015) Stratégie technique mondiale de lutte contre le paludisme 2016-2030, $36 \mathrm{p}$

3. OMS (2018) World malaria report, $210 \mathrm{p}$

4. OMS (2019) Questions et réponses sur le programme de mise en œuvre de la vaccination antipaludique (MVIP) [en ligne]

5. Pays J-F (2010) Une moustiquaire pour tous en 2010. Bull Soc Pathol Exot. 103(4):223-9 [http://www.pathexo.fr/documents/articles-bull/sprexot000063.pdf] 